\title{
Tiroides lingual: un nuevo abordaje quirúrgico
}

\section{Lingual thyroid: a new surgical approach}

\author{
I. Zubillaga Rodríguez', G. Sánchez Aniceto², I. García Recuero², J.J. Montalvo Moreno3
}

Resumen: El tiroides lingual es una rara anomalía congénita del desarrollo tiroideo resultante de la ausencia de descenso del mismo desde el foramen caecum hasta la localización prelaríngea habitual.

Presentamos el caso de una paciente en edad postmenopáusica con diagnóstico anatomopatológico de tiroides lingual de gran tamaño y localización profunda en la base de la lengua que producía disfagia y dificultad respiratoria crecientes. Asimismo, planteamos un nuevo abordaje quirúrgico para la resección combinando cervicotomía media, pull-through lingual y glosotomía media.

Se discuten las distintas pruebas complementarias para llegar a su diagnóstico y se revisan las diferentes técnicas quirúrgicas habitualmente empleadas en su tratamiento concluyendo con las ventajas del abordaje empleado en este caso.

Palabras clave: Tiroides lingual; Pull- through lingual; Glosotomía; Abordajes cervicales.
Abstract: Lingual thyroid is an uncommon congenital disorder of thyroid gland development, resulting in a lack of descend of the gland from the foramen caecum to his normal prelaringeal location. In this paper we present a case of a postmenopausic patient presenting with a big size lingual thyroid deeply located in the base of the tongue, suffering increasing disphagia and respiratory impairment. For tumor resection, we chose a surgical approach combining a cervical submental incision, lingual pull- through and midline glossotomy.

We discuss the different image studies recommended for proper diagnosis also reviewing the most common surgical techniques used for treatment, as compared with the approach we have described in this case.

Key words: Lingual thyroid; Lingual pull-through; Glossotomy; Transcervical approaches.

\footnotetext{
1 Médico Residente

2 Médico Adjunto

3 Jefe de Servicio

Servicio de Cirugía Oral y Maxilofacial

Hospital Universitario "12 de Octubre", Madrid, España.

Correspondencia:

Ignacio Zubillaga Rodríguez

Servicio de Cirugía Oral y Maxilofacial. Hospital Universitario "12 de Octubre"

Avda. de Córdoba s/n

28041 Madrid, España.

E-mail: ignaciozubillaga@yahoo.es
} 


\section{Introducción}

Embriológicamente, el tiroides deriva de tres fuentes primitivas. ${ }^{1}$ Un divertículo endodérmico en el área del foramen caecum en la línea media de la base de la lengua aparece sobre la tercera semana de gestación entre la primera y segunda bolsas faríngeas, migrando posteriormente hacia el cuello hasta alcanzar su posición definitiva. Dará lugar a la mayor parte del tejido tiroideo funcionante. En la séptima semana, ya en su localización prelaríngea, recibe la fusión de dos masas laterales de células derivadas de las cuartas bolsas faríngeas, siendo un proceso inconstante. ${ }^{2}$ Dan lugar a las células C parafoliculares y al $1-30 \%$ del peso total tiroideo. ${ }^{3}$ En ese momento el conducto tirogloso ha comenzado a atrofiarse. Remanentes del tejido tiroideo a lo largo del trayecto migratorio del divertículo principal dan lugar a la formación de quistes del conducto tirogloso que pueden estar presentes en cualquier lugar desde el foramen caecum hasta el área prelaríngea pasando por el hueso hioides. ${ }^{4}$

El fallo total en la migración embrionaria produce clínicamente el tiroides lingual sin tejido tiroideo funcional en su posición cervical normal en la mayoría de los casos.

La presencia de tejido tiroideo ectópico ( $90 \%$ de los casos en la lengua) también ha sido descrito en otras localizaciones como la línea media del cuello cerca del hueso hioides, la tráquea, el esófago e incluso a distancia como la porta hepática, corazón y diafragma.

La patogenia permanece desconocida. ${ }^{5}$ Se ha postulado que inmunoglobulinas antitiroideas maternas pueden detener el descenso glandular y predisponer al paciente a una pobre función tiroidea en vida.

Aunque el tiroides lingual es la masa benigna más frecuentemente encontrada en la unión de los dos tercios anteriores y el tercio posterior lingual entre la epiglotis y las papilas circunvaladas es una entidad clínica rara. ${ }^{6}$ Estudios postmortem han mostrado una incidencia de $10 \%$ de tiroides linguales. ${ }^{4}$ La incidencia clínica, sin embargo, varía entre 1: 3.000 y $1: 10.000^{7}$ siendo el tiroides lingual el único tejido tiroideo funcionante en el $70 \%$ de los casos. ${ }^{8}$ La presencia de tejido tiroideo ectópico es 3 ó 4 veces más frecuente en mujeres que en varones aunque algunos autores estiman que la proporción puede ser de hasta 7:1.9

Su tamaño varía desde unos milímetros hasta varios centímetros y los síntomas y signos se relacionan directamente con el tamaño del mismo. La mayoría de pacientes se encuentran asintomáticos y su hallazgo se produce en un examen oral rutinario. Las lesiones sintomáticas pueden aparecer en cualquier momento desde el nacimiento hasta la edad adulta. En aquellos presentes al nacimiento es muy probable que todo o casi todo el tejido tiroideo se encuentre en la lengua. Este es el lugar más frecuente de localización de ectopias tiroideas totales. La mayoría de los tiroides linguales sintomáticos surgen durante la pubertad, el embarazo o la menstruación. La media de edad de aparición de manifestaciones clínicas es de 40 años, con dos picos de mayor incidencia a los 12 y 40 años. ${ }^{3}$

Como hemos visto, signos y síntomas se relacionan directamente con el tamaño lesional y consisten en disfagia, disfonía, disnea, sen-

\section{Introduction}

Embryologically, the thyroid is derived from three primary sources. ${ }^{1}$ An endodermic diverticulum in the area of the foramen caecum in the midline on the base of the tongue appears during the third week of gestation, between the first and second pharyngeal pouches, migrating later to the neck until it reaches its definitive position. This will turn into the greater part of the functional thyroid tissue. In the seventh week, now in its prelaryngeal position, the fusion of two lateral masses of cells derived from the four pharyngeal pouches is attached, being an inconsistent process. ${ }^{2}$ Parafollicular $C$ cells arise representing 1-30\% of the total weight of the thyroid. ${ }^{3}$ At this point the thyroglossal duct becomes atrophied. Remains of the thyroid tissue along the migratory route taken by the principal diverticulum give rise to the formation of cysts in the thyroglossal duct that can be present in any area from the foramen caecum to the prelaryngeal area passing through the hyoid bone. ${ }^{4}$

Total failure of embryonic migration gives rise to a lingual thyroid which clinically does not have, in the majority of cases, functional thyroid tissue in its normal cervical position. The presence of ectopic thyroid tissue (90\% of cases involving the tongue) has also been described in other locations such as in the midline of the neck near the hyoid bone, trachea, esophagus and even in distant locations such as in the porta hepatis, heart and diaphragm.

The pathogeny remains unknown5. Maternal antithyroid immunoglobulins have been claimed as stopping the descent of the gland and predisposing patients to a poorly functioning thyroid gland through out their lifetime.

Even though lingual thyroid is a benign mass most commonly found at the junction of the anterior two thirds and the posterior third, between the epiglottis and the circumvallate papillae, clinically it is a rare entity. ${ }^{6}$ Postmortem studies have showed an incidence of $10 \%$ of lingual thyroid. ${ }^{4}$ Clinical incidence varies. However, between 1:3000 and 1:100007 lingual thyroid is the only functioning thyroid tissue in $70 \%$ of cases. ${ }^{8}$ The presence of ectopic thyroid tissue is 3 or 4 times more frequent in women than in men even though some authors estimate that the proportion can be $7: 1.9$

Its size varies from a few millimeters to various centimeters and symptoms and signs are directly related to its size. Most patients are asymptomatic and discovery is made during routine oral examination. Symptomatic lesions may appear at any moment from birth until adulthood. It is probable in the cases present at birth that all the thyroid tissue, or nearly all of it, is found in the tongue. This is the most common area for finding totally ectopic thyroids. Most symptomatic cases of lingual thyroid appear during puberty, pregnancy or menstruation. The average age for clinical manifestation is 40, with two peaks of greater incidence at 12 and 40.3

As we have seen, signs and symptoms are directly related to lesion size and these consist in dysphagia, dysphonia, 
sación de cuerpo extraño y ocasionalmente hemorragia. Un $10 \%$ de los pacientes jóvenes presenta mixedema juvenil o cretinismo. ${ }^{10}$ Aproximadamente, el $70 \%$ de los pacientes presenta hipotiroidismo y entre $2 / 3$ y $3 / 4$ de los pacientes sintomáticos no tienen otro tejido tiroideo funcional. Se ha descrito una alta incidencia de patología tiroidea en miembros de la familia de pacientes con tiroides lingual.

Puede estar circunscrito pero la mayoría de los casos es encontrado tejido tiroideo interdigitándose con músculo esquelético y glándulas salivares menores en la base de la lengua. Generalmente presenta tejido tiroideo embrionario, tejido tiroideo maduro o una combinación de ambos. El tejido tiroideo ectópico no presenta mayor riesgo de degeneración maligna en comparación con la glándula tiroides. La presencia de carcinoma en tejido tiroideo ectópico es extremadamente rara siendo aproximadamente del 1\%. ${ }^{11}$ La mayoría de casos descritos son carcinomas foliculares, presentándose con más frecuencia en la tercera década de la vida. ${ }^{3}$ El tiroides lingual no se asocia con las glándulas paratiroides, normalmente situadas en su porción posterior, ya que éstas se originan del ala dorsal de la tercera y cuarta bolsas faríngeas (presentan un origen embriológico diferente).

\section{Caso clínico}

Una mujer caucásica de 56 años fue remitida a la consulta de cirugía oral y maxilofacial presentando disfagia progresiva de 6 meses de evolución. Asimismo refiere sensación de cuerpo extraño acentuada en el momento de la deglución. Entre sus antecedentes personales destacan retraso psicomotor con situación límite del cociente intelectual y limitación funcional en miembro inferior derecho. Presenta talla baja e hipotiroidismo nunca valorado.

En la exploración intraoral se objetiva vagamente una tumoración violácea, vascularizada, dura y no dolorosa a la palpación en línea media lingual tras el foramen caecum (Fig. 1). La superficie tumoral visible no presenta ulceraciones. No se palpan adenopatías cervicales. Se solicita RM (Fig. 2) donde se objetiva una masa uniforme en base de lengua de aproximadamente $5 \times 4 \mathrm{~cm}$ compatible con tiroides lingual con obstrucción severa de la línea aérea. Se completa el estudio con una gammagrafía isotópica con Tc ${ }^{99}$ donde se distingue acentuada captación en base de lengua sin captación dyspnea, foreign body sensation and occasionally hemorrhaging. $10 \%$ of young patients present juvenile myxedema or cretinism. ${ }^{10}$ Approximately $70 \%$ of patients present hypothyroidism and between two thirds and three quarters of symptomatic patients do not have any other functional thyroid tissue. A greater frequency of thyroid pathology has been reported in the family members of patients with lingual thyroid.

This can be limited but in the majority of cases thyroid tissue had been found interdigitated with skeletal muscles and in minor salivary glands at the base of the tongue. Generally embryonic thyroid tissue is presented, mature thyroid tissue or a combination of both. Ectopic thyroid tissue does not represent a greater risk of malignant degeneration compared with the thyroid gland. The presence of carcinoma in ectopic thyroid tissue is extremely rare, representing approximately $1 \% .{ }^{11}$ The majority of cases described are follicular carcinomas, which are presented more frequently in the third decade of life. ${ }^{3}$ Lingual thyroid is not associated with the parathyroid glands, which are normally positioned in the posterior area, as these originate from the dorsal part of the third and fourth pharyngeal pouches (having a different embryologic origin).

\section{Clinical Case}

A 56-year-old Caucasian female was sent to the Maxillofacial Surgery and presented with a six-month history of progressive dysphagia. She complained of a foreign body sensation that was more accentuated on swallowing. Her personal history included psychomotor retardation and borderline intellectual functioning. Her right leg had functional limitation. She was short and had hypothyroidism that 
en la posición prelaríngea habitual hioidea. Se remite al endocrinólogo para control de su función tiroidea y con el diagnóstico de presunción de tiroides lingual se decide intervención quirúrgica dada la progresiva disfagia obstructiva.

Bajo anestesia general se realiza inicialmente una traqueostomía que asegure adecuadamente la vía aérea dado el importante tamaño y localización posterior tumoral en la base lingual. Se practica una cervicotomía media suprahioidea (Fig. 3) combinada con desperiostización de la tabla lingual mandibular y posterior pull-through lingual (Fig. 4) que amplía el control quirúrgico en el momento de la resección. Dada la situación posterior y profunda tumoral es precisa la realización de una glosotomía media (Fig. 5) exangüe que permite la exéresis tumoral completa (Fig. 6) bajo control directo sin lesión asociada de estructuras adyacentes vitales (Fig. 7). Finalmente se cierran por planos las vías de abordaje (Figs. 8 y 9).

La paciente presenta una evolución excelente siendo decanulada en el postoperatorio inmediato.

La anatomía patológica confirma el diagnóstico de tiroides lingual. La RM de control (Fig. 10) objetiva ausencia de tejido tiroideo lingual.

Es seguida en revisiones periódicas por nuestra parte y por el endocrinólogo con control de su hipotiroidismo basal.

\section{Discusión}

El tiroides lingual es una rara anomalía congénita del desarrollo tiroideo resultante de la ausencia de descenso del mismo desde el foramen caecum hasta su localización prelaríngea. Usualmente se presenta como un nódulo submucoso en la base de la lengua.

Hickman, ${ }^{12}$ en 1869, fue el primero en descubrirlo en un caso de un neonato de sexo femenino que murió por asfixia a causa de un tiroides lingual 16 horas tras el nacimiento. En un $70 \%$ de los pacientes con tiroides lingual la glándula está enteramente contenida en la lengua y cerca de un $70 \%$ de los casos están asociados con diversos grados de hipotiroidismo, comúnmente precipitado por situaciones de incremento de la demanda fisiológica de hormonas tiroideas. En cualquier caso muchos pacientes están asintomáticos durante gran parte de su vida o incluso no llegan a precisar atención médica.

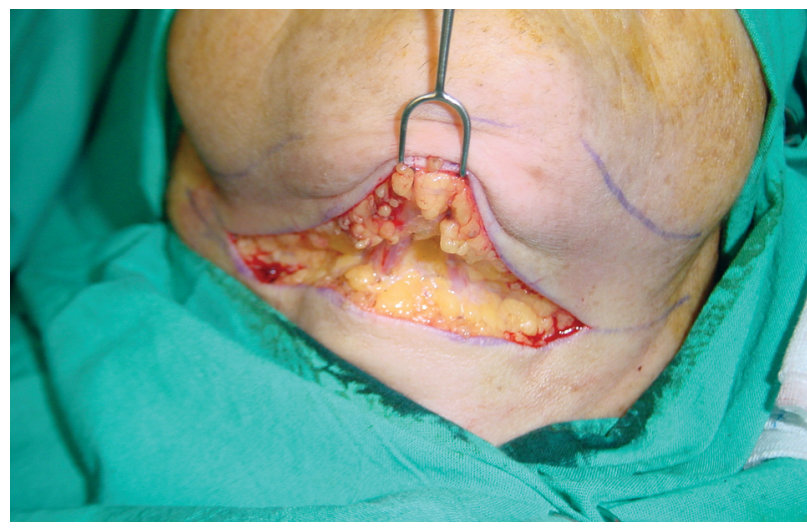

Figura 3. Cervicotomía suprahioidea.

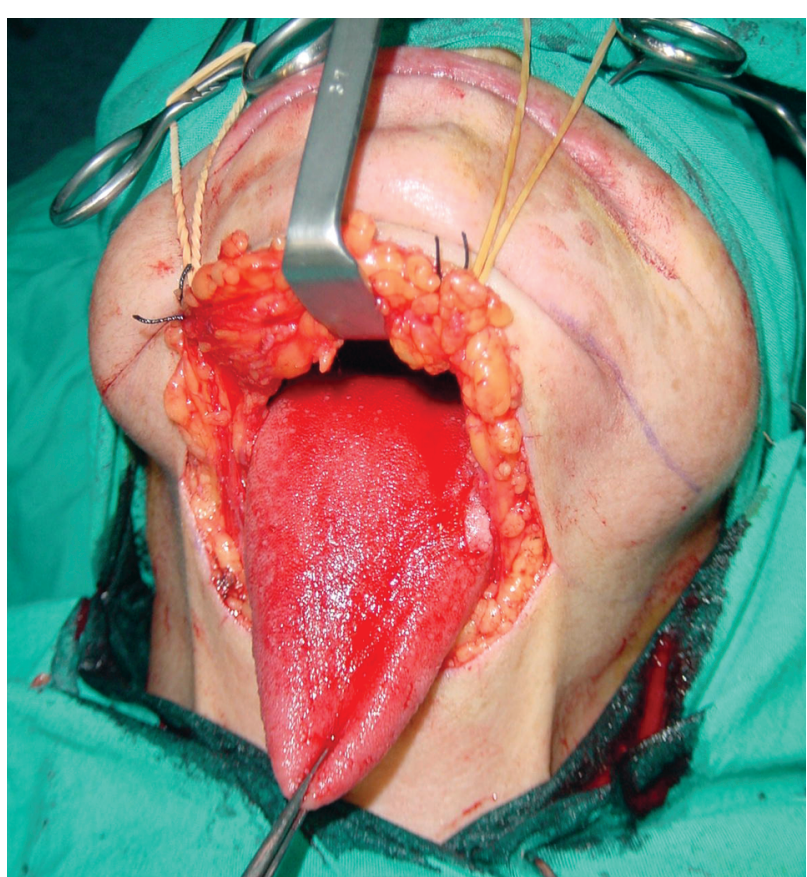

Figura 4. "Pull-throung" lingual. Figure 4. Lingual pull-through. had never been evaluated. During the intraoral examination a purplish vascularized tumor was vaguely distinguished which was hard, not painful on palpation and in the midline of the tongue after the foramen caecum (Fig. 1). The tumor surface, which was visible, did not show ulceration. Palpation did not reveal cervical adenopathies. An MR test was requested (Fig. 2) in which a uniform mass at the base of the tongue was visible measuring approximately $5 \times 4 \mathrm{~cm}$. It was compatible with lingual thyroid with severe airway obstruction. The study was completed with an isotopic gammagraphy with $T c^{99}$ that showed significant enhancement at the base of the tongue with no contrast enhancement in the normal prelaryngeal position of the hyoid. This was sent to the endocrinologist for thyroid function control, and with the diagnosis of a probable lingual thyroid, surgical intervention was decided upon given the progressive obstruction due to dysphagia.

First a tracheotomy was performed under general anesthesia in order to ensure airway protection given the considerable size and posterior location of the tumor at the base of the tongue. A suprahyoid midline cervicotomy was carried out (Fig. 3) together with periosteum removal of the mandibular lingual plate, followed by a lingual pull-through (Fig. 4) which was enlarged for surgical control during the resection.

A blood free midline glossotomy was performed given the posterior location and the depth of the tumor (Fig. 5), which permitted complete tumor excision (Fig. 6) under direct control with no associated lesion to adjacent vital structures (Fig. 7). Finally the approach sites were closed in layers (Fig. 8 and 9).

The patient made an excellent recovery and all tubes were removed during the immediate postoperative period.

Pathological anatomy confirmed the diagnosis of lingual 
La evaluación inicial del tiroides lingual está basada en los síntomas clínicos: disfagia, disfonía, disnea, hemorragia. El estridor puede aparecer en cualquier momento pero es más común en neonatos.

El tiroides lingual se presenta generalmente bajo uno de los siguientes cuadros clínicos: niños o adultos jóvenes cuyo tiroides lingual es detectado en un screening rutinario. Estos pacientes a menudo presentan retraso del crecimiento y retraso mental. En el segundo grupo, el inicio de los síntomas coincide con situaciones en las que existe incremento en la demanda metabólica de hormonas tiroideas (pubertad, embarazo o menopausia). El incremento de los niveles de TSH provoca aumento del tamaño glandular. ${ }^{6}$

El examen clínico intraoral revela la presencia de una masa suave, irregular y muy vascularizada en la línea media de la base de la lengua tras las papilas circunvaladas. En ocasiones se encuentra ulcerado dando lugar a hemorragias frecuentes. Una exploración con endoscopio rígido o flexible de la vía aérea superior determina el tamaño glandular y la permeabilidad aérea. Es imperativo una cuidadosa palpación cervical pretraqueal en el lugar habitualmente normal de la glándula.

Los primeros estudios de laboratorio precisos son los test de función tiroidea. A menudo demuestran situaciones de eutiroidismo o hipotiroidismo con niveles normales o bajos de T3 y T4 y niveles altos de TSH y tiroglobulina. EI hipertiroidismo, aunque infrecuente, ha sido descrito. El estudio mas específico para el diagnóstico del tiroides lingual es la gammagrafía con $\mathrm{TC}^{99} \mathrm{O} \mathrm{I}^{131}$. Muestra actividad o captación del radionucleótido en la base de la lengua y no aparente actividad en la posición normal de la glándula en el cuello. Este método evita la necesidad de realizar una biopsia diagnósti$\mathrm{ca}$, la cual implica riesgo de hemorragia incoercible o tirotoxicosis aguda.

Respecto a las pruebas de imagen, la TC es útil en la determinación del tamaño glandular. Sin embargo la mejor técnica no invasiva es la RM permitiendo imágenes multiplanares y una excelente definición de los tejidos blandos. Muestra con precisión el tamaño y la localización lesional. La intensidad de señal del tejido tiroideo normal es mayor que el tejido muscular en T1 y T2. Las calcificaciones y los quistes intraglandulares son mejor apreciados en secuencias T2. En el momento actual, los estudios ecográficos han

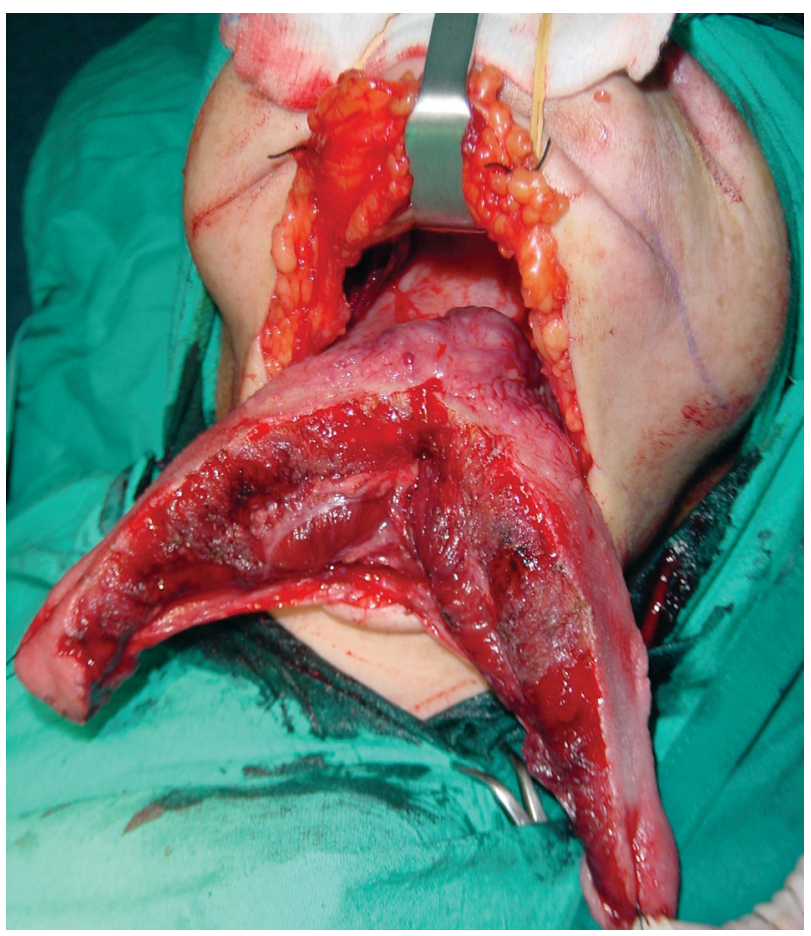

thyroid. The MR control (Fig. 10) showed an absence of lingual thyroid tissue.

She underwent periodic checkups by us and by the endocrinologist controlling her basal hypothyroidism.

\section{Discussion}

Lingual thyroid is a rare congenital anomaly of thyroid development as a result of it not descending from the foramen caecum to its prelaryngeal location. It usually appears as a submucous nodule at the base of the tongue.

Hickman ${ }^{12}$ in 1869 was the first to make its discovery in a case of a neonatal female that died of suffocation as a result of a lingual thyroid 16 hours after birth. In 70\% of patients with lingual thyroid the gland is completely contained in the tongue and nearly $70 \%$ of cases are associated with different grades of hypothyroidism, a condition commonly brought on by increases in the physiological demand of thyroid hormones. In any event, many patients are asymptomatic during most of their lives or may not even require medical attention.

The initial evaluation of lingual thyroid is based on clinical symptoms: dysphagia, dysphonia, dyspnea, hemorrhage. The stridor can appear at any time but it is more common in neonatal infants.

Lingual thyroid is generally presented within one of the following clinical descriptions: children or young adults with lingual thyroid detected during routine screening. These patients often have retarded growth and mental development. In the second group, the start of symptoms coincides with situations in which there is an increase in metabolic demand of thyroid hormones (puberty, pregnancy or menopause). The increase in TSH levels leads to an increase in the size of the gland. 6

Intraoral clinical examination reveals the presence of a smooth, irregular and well vascularized mass in the mid- 
perdido importancia respecto a las técnicas ya descritas. La angiografía selectiva de carótida externa puede detectar patrones aberrantes de vascularización. La arteria tiroidea superior en ocasiones está ausente y el tiroides lingual recibe su vascularización desde la arteria lingual y facial. ${ }^{6}$ La embolización previa a la cirugía de los vasos nutrientes es el método mas seguro desde el punto de vista quirúrgico.

El diagnóstico diferencial debe incluir quistes del conducto tirogloso, teratomas, quistes dermoides, linfadenitis, linfangiomas, lipomas, fibromas, carcinomas de células escamosas, tumores de glándulas salivares menores y linfomas.

No existe un consenso real en la literatura sobre el adecuado manejo del tiroides lingual debido a la rareza de esta condición y a las escasas y cortas series publicadas. Sin embargo, parece claro que los objetivos básicos a cubrir son la exéresis completa que elimine la presencia de síntomas obstructivos que en ocasiones puedan poner en peligro la vida del paciente y el control de la función tiroidea.

El tratamiento depende de una serie de factores: severidad de los síntomas, tamaño de la lesión, sexo y edad del paciente y función tiroidea. Pacientes eutiroideos con tiroides linguales asintomáticos deben ser vigilados regularmente sin necesidad de tratamiento. ${ }^{13}$ Si un tiroides lingual no causa síntomas obstructivos debido a su tamaño, en principio no existe necesidad de tratamiento quirúrgico y si presenta síntomas de hipotiroidismo puede ser tratado únicamente con suplementos de hormona tiroidea. Asimismo, la terapia supresiva con hormona tiroidea se convierte en la pieza clave en el manejo médico de la situación. El objetivo es suprimir los niveles de TSH y eliminar así el estímulo de crecimiento glandular. Sin embargo, no siempre consigue disminuir el tamaño lesional y en ocasiones implica una terapia prolongada para apreciar cambios significativos en la reducción del tiroides. Está indicada en pacientes con síntomas moderados y en pacientes asintomáticos con niveles elevados de TSH. La función tiroidea debe ser monitorizada en intervalos regulares, idealmente cada 3 meses.

La ablación con dosis terapéuticas de $\mathrm{I}^{131}$ radiactivo es un método alternativo de tratamiento que implica aporte exógeno de hormona tiroidea de por vida. Particularmente contraindicado en mujeres en edad fértil, quedaría reservado para pacientes que recha-

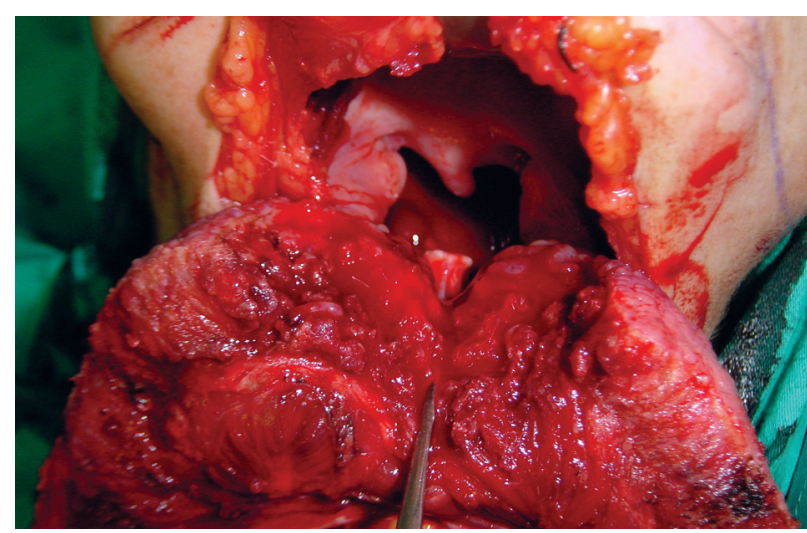

Figura 7. Campo quirúrgico tras la resección.

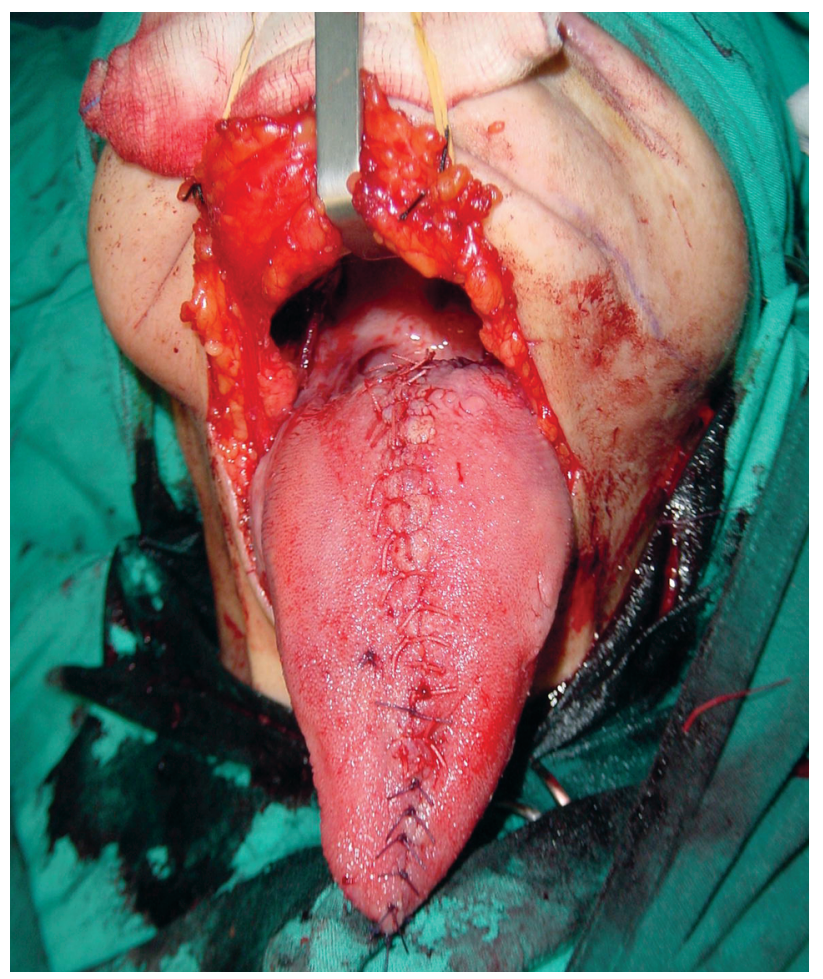

Figura 8. Cierre del abordaje lingual.

Figure 8. Closure of the lingual approach. line of the tongue after the circumvallated papillae. On occasions this is ulcerated giving rise to frequent hemorrhages. Exploration with a rigid or flexible endoscope of the upper airway establishes the size of the gland and air permeation. Careful pretracheal cervical palpation in the usually normal position of the gland is imperative.

The first laboratory studies that are precise are thyroid function tests. These often shown euthyroidism or hypothyroidism conditions with normal or low levels of T3 and T4 and high TSH and thyroglobulin levels. Hyperthyroidism although less frequent has been described. The most specific study for the diagnosis of lingual thyroid in the gammagraphy with $T C^{99}$ or 1131 . It shows activity or radionucleotide uptake at the base of the tongue and no apparent activity in the normal position of the gland in the neck. This method avoids the need for performing a diagnostic biopsy, which carries the risk of an unstoppable hemorrhage or acute thyrotoxicosis.

With regard to imaging tests CT scans are useful for determining the size of the gland. However, the best non-invasive technique is RMI which permits multiplane imaging and an excellent definition of soft-tissues. The size and location of the lesion are shown with precision. Signal intensity of normal thyroid tissue is greater than that of muscular tissue in T1 and T2 [weighted sequences]. Calcifications and intraglandular cysts are appreciated better in T2 [weighted sequences]. Currently echographic studies have lost importance with regard to the techniques described. A selective angiography of the external carotid [artery] may detect an aberrant vascularization pattern. The superior thyroid artery is sometimes absent and the lingual thyroid receives vascularization from the lingual and facial artery. ${ }^{6}$ Embolization of the nutrient vessels 
zan el tratamiento quirúrgico. Entre sus desventajas se añade la fibrosis y el desarrollo de mixedema tardío. ${ }^{13}$

El tratamiento quirúrgico debe ser considerado en aquellos casos que por su tamaño provocan síntomas obstructivos y/o hemorrágicos, cuando existe sospecha de malignidad y en casos en los que los síntomas iniciales empeoran tras la terapia supresiva. Sin embargo, en pacientes sintomáticos, el tratamiento conservador con hormona tiroidea debe ser administrado previamente al tratamiento quirúrgico con el objetivo de reducir el tamaño tumoral. La intubación de pacientes con tiroides lingual puede tener serias complicaciones desde el punto de vista hemorrágico. Además, el edema postoperatorio puede causar compromiso de la vía aérea, de ahí la necesidad de considerar la traqueostomía como procedimiento quirúrgico inicial. Así, la traqueostomía profiláctica ha sido defendida por algunos autores, 14 mientras otros prefieren su realización en aquellos pacientes que muestran compromiso de vía aérea precoz en el postoperatorio inmediato.

Respecto al tratamiento quirúrgico, nunca debemos olvidar que nuestro objetivo es la exéresis completa lesional. Cuando el tiroides lingual está asociado con tejido tiroideo funcionante en su localización habitual, la excisión total es curativa; en caso contrario, el reimplante del tejido tiroideo ectópico extirpado es la forma de tratamiento adecuado para evitar el desarrollo de un estado hipotiroideo que precise aporte hormonal tiroideo de por vida.

La excisión quirúrgica del tiroides lin-

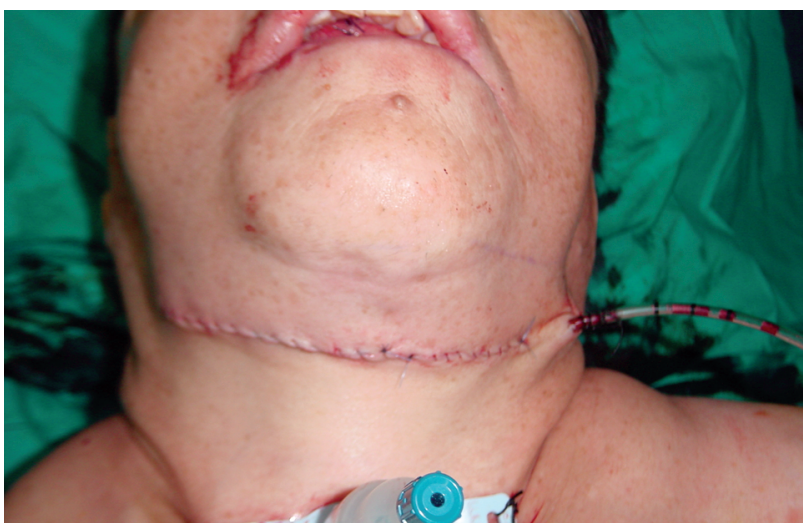

Figura 9. Cierre de la incisión cervical. Figure 9. Closure of the neck incission.

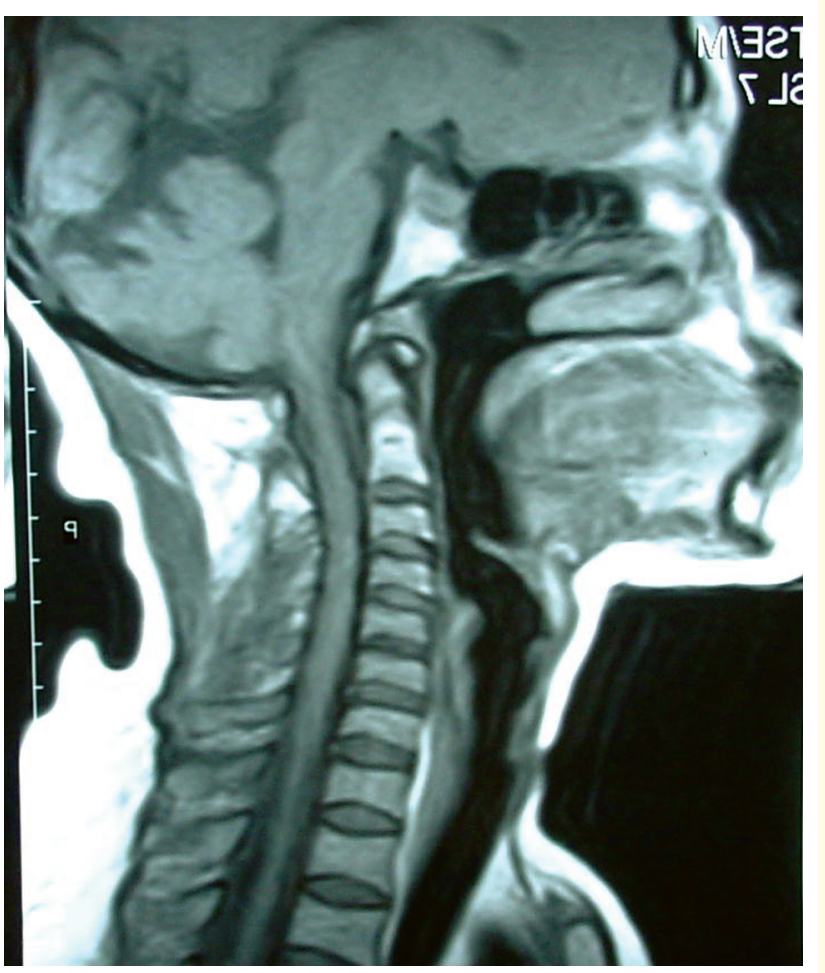

Figura 10. RM postoperatoria. Figure 10. Postoperatory MR. prior to surgery is the most secure method from the surgical point of view.

The differential diagnosis should include cysts of the thyroglossal duct, teratomas, dermoid cysts, lymphadenitis, lymphangiomas, lipomas, fibromas, squamous cell carcinomas, tumors of minor salivary glands and lymphomas.

There is no real consensus in the literature as to the adequate management of lingual thyroid due to the rarity of this condition and to the series that have been published being both scarce and short. However, it appears to be clear that the basic objectives to be met are complete excision, thus eliminating the presence of obstructive symptoms that may sometimes endanger the life of the patient, and thyroid function control.

Treatment depends on a series of factors: severity of the symptoms, size of the lesion, sex and age of the patient and thyroid function. Euthyroid patients with asymptomatic lingual thyroids should be regularly followed, with treatment being unnecessary..$^{13}$ If a lingual thyroid does not cause symptoms of obstruction due to size, in principle there is no need for surgical treatment, and if hypothyroid symptoms are presented, thyroid hormone supplements can be used on their own. Likewise suppressive therapy with thyroid hormones becomes the key factor in the medical management of the condition. The objective is to suppress the levels of TSH and to eliminate the growth stimulus of the gland. However, not always can the size of the lesion be reduced and on occasions prolonged therapy is involved before significant changes in thyroid reduction can be appreciated. It is indicated for patients with moderate symptoms and for asymptomatic patients with high levels of TSH. Thyroid function should be monitored at regular intervals, ideally every 3 months.

Ablation with therapeutic doses of radioactive ${ }^{131}$ is an a través de incisiones cervicales separadas previas a la glosotomía media. En ocasiones se ha asociado a necrosis masiva lingual. Atico adecuado y el riesgo de infección y fístula orocervical postoperatoria es menor. Sin embargo, ofrece peor exposición para grandes masas lesionales y favorece un inadecuado control de la posible hemorragia intraoperatoria. Kamat y cols., ${ }^{15}$ describen la ligadura bilateral de las arterias linguales a nivel del cuerno del hioides 
yeh, ${ }^{4}$ introduce la glosotomía media solo en los dos tercios posteriores de la lengua minimizando así el riesgo de lesión de estructuras vitales.

El abordaje cervical ofrece una mejor visualización global de la lesión, siendo especialmente útil en casos de gran tamaño y localización posterior. Existen menos posibilidades de hemorragia intraoperatoria y cuando ocurre el control es mas sencillo. Entre sus desventajas figuran la cicatriz cervical y la fístula orocervical postoperatoria.

Puede realizarse a través de una faringotomía media trans, supra o infrahioidea o a través de una faringotomía lateral.

Algunos autores, ${ }^{16}$ combinan técnicas transorales y transcervicales en el manejo del tiroides lingual. Obtienen los beneficios de cada método. La movilización de la porción posterior de la glándula vía faringotomía permite el control de zonas con potencial hemorrágico elevado. Permite posteriormente el desplazamiento anterior de la masa para facilitar su resección completa. En nuestro caso clínico presentamos un nuevo abordaje que combina técnica extraoral inicial mediante cervicotomía media con posterior descenso lingual (pull-through) y glosotomía media final. De esta forma aseguramos una franca exposición lesional que permite su exéresis completa con control adecuado de estructuras vitales cervicales sin añadir morbilidad a los procedimientos clásicos.

El autotrasplante del tiroides lingual tras su exéresis está indicado en pacientes con ausencia de tejido tiroideo normal funcionante fuera de la línea media lingual. El tejido es colocado como un injerto libre bajo la fascia del músculo recto anterior del abdomen o en la región submandibular tras ser seccionado en láminas de 4-5 mm de espesor. ${ }^{17}$ El tratamiento con tiroxina no es administrado en el postoperatorio inmediato para prevenir la supresión del injerto. Un 30\% de los pacientes permanecen eutiroideos sin la terapia con tiroxina. ${ }^{6}$

Una alternativa al autotrasplante consiste en la trasposición del tiroides lingual desde la base de la lengua a la región submandibular a través de una faringotomía lateral suprahioidea. ${ }^{18}$ Se crea un colgajo pediculado, randomizado de musculatura lingual que vehicula el tiroides lingual. Según sus autores, ofrece un mejor resultado en la función tiroidea comparado con la escisión y el autotrasplante. Defienden una posible exploración en su nueva localización más accesible en caso de hipertrofia o malignización.

El uso de láser ha sido descrito en el manejo quirúrgico de un tiroides lingual en un niño de 6 años. ${ }^{19}$

\section{Conclusiones}

Aunque las técnicas transorales son simples y satisfactorias en el manejo de pequeñas lesiones, el abordaje cervical es imprescindible en el manejo de tiroides linguales grandes y profundos en el espesor muscular. La combinación de técnicas aumenta la exposición tumoral, asegura su resección completa y minimiza la morbilidad intraoperatoria derivada del control de estructuras cervicales vitales. alternative method of treatment which implies the exogenous supplement of thyroid hormones for life. This is particularly contraindicated in women of a fertile age, and should be reserved for patients who have rejected surgical treatment. Disadvantages include fibrosis and the development of tardive myxedema. ${ }^{13}$

Surgical treatment should be considered for those cases in which symptoms of obstruction and/or hemorrhages are produced because of size, when malignancy is suspected, and in cases in which the initial symptoms worsen after suppressive therapy. However, in symptomatic patients, conservative treatment with thyroid hormones should be administered before surgical treatment with the aim of reducing the size of the tumor. Intubation of patients with lingual thyroid can have serious complications from the point of view of hemorrhaging. In addition, postoperative edema can cause airway compromise, and a tracheotomy should therefore be considered as the initial surgical procedure. Prophylactic tracheostomies have as a result been defended by certain authors ${ }^{14}$ while some others prefer to perform these on those patient showing early airway compromise during the immediate postoperative period.

With regard to surgical treatment, we should never forget that our objective is complete exeresis of the lesion. When lingual thyroid is associated with functioning thyroid tissue in its habitual position, total excision is curative; in the opposite case, reimplantation of the ectopic thyroid tissue that has been removed is the most adequate form of treatment in order to avoid the development of a hypothyroid state that would require life-long thyroid hormone treatment.

Surgical excision of lingual thyroid can be carried out transorally or through a midline cervicotomy or lateral pharyngotomy.

Most of the cases described in the literature have been resolved using a transoral approach. Different modifications have been introduced with the object of improving exposure such as incising the full thickness of the cheek, midline lipsplit, midline mandibulotomy with lip split, and/or midline glossotomy. ${ }^{4}$ It offers an adequate aesthetic result and the risk of infection and of postoperative orocervical fistulas is reduced. However, exposure of larger lesion masses is worse being conducive to inadequate control of possible intraoperative hemorrhages. Kamat et al ${ }^{15}$ describe bilateral ligation of lingual arteries at the level of the horn of hyoid using cervical incisions separated before the median glossotomy. On occasions this has led to massive lingual necrosis. Atiyeh4 introduces a median glossotomy only in the posterior two thirds of the tongue thus minimizing the risk of damaging vital structures.

The cervical approach offers a better global visualization of the lesion, and is especially useful for large size cases with a posterior location. There are less possibilities of intraoperative hemorrhaging and, should it occur, control is easier. Among the disadvantages are cervical scarring and postoperative orocervical fistulas. This can be done using a mid- 


\section{Bibliografía}

1. Volpe R. The thyroid. En: Systemic Endocrinology. Harper and Row, Maryland, 1973;55-6.

2. Ward G E, Canterell JR, Allan WB. The surgical treatment of lingual thyroid. Ann Surg 1954;139:536-44.

3. Batsakis JG, El- Naggar AK, Luna MA. Pathology consultation. Thyroid gland ectopias. Ann Otol Rhinol Laryngol 1996;105:996-1000.

4. Atiyeh BS, Abdelnour A, Haddad FF, Ahmad H. Lingual thyroid: tongue splitting incision for transoral excision. J Laryngol Otol 1995;109: 520-4.

5. Okstad S, Mair IW, Sundsfjord JA, y cols. Ectopic thyroid tissue in the head and neck. J Otolaryngol 1986;15:52-5.

6. Kalan A, Tariq M. Lingual thyroid gland: clinical evaluationa and comprehensive management. Ear Nose Throat / 1999;78:340-6.

7. Williams ED, Toyn CE, Harach HR. The ultimobranchial gland and congenital thyroid abnormalities in man. J Pathol 1989;159:135-41.

8. Al- Samarrai AY, Crankson SJ, Al- Jobori A. Autotransplantation of lingual thyroid into the neck. Br / Surg 1988;75:287.

9. Alderson DJ, Lannigan FJ. Lingual thyroid presenting after thyroglossal cyst excision. J Laryngol Otol 1994;108:341-3.

10. Larochelle D, Arcand P, Belzile M, Gagnon N B. Ectopic thyroid tissue -a review of the literature. J Otolaryngol 1979;8:523-30.

11. Sastre Perez J, Muñoz M, Naval L, Blasco A, Diaz FJ. Papillary carcinoma arising in lingual thyroid. / Cranio-Maxillofacial Surg 2003;31:179-82.

12. Hickman W. Congenital tumour of the base of the tongue, pressing down the epiglottis on the larynx and causing the death of by suffocation sixteen hours after birth. Trans Pathol Soc. (London) 1869;20:160-3.

13. Vairaktaris E, Semergidis T, Christopoulou P, Papadogeorgakis N, Martis C. Lingual thyroid: a new surgical approach- a case report. J Cranio-Maxillo- Facial Surg 1994;22:307-0.

14. Steinwald OP, Muehrcke RC, Economou SG. Surgiccal correction of complete lingual ectopia of the thyroid gland. Surg Clin North Am 1970;50:1177-86.

15. Kamat MR, Kulkarni JN, Desai PB, Jussawalla DJ. Lingual thyroid: a review a 12 cases. Br / Surg 1979;63:537-9.

16. Zitsman JL, Lala VR, Rao PM. Combined cervical and intraoral approach to lingual thyroid: a case report. Head Neck 1998;20:79-82.

17. Al- Samarrai AY, Crankson SJ, Al Jabori. Autotransplantation of lingual thyroid into the neck. Br / Surg 1988;75:287-90.

18. Rojananin S, Ungkanont K. Transposition of the lingual thyroid: a new alternative technique. Head Neck 1999;21:480-3.

19. Chanin LR, Greenberg LM. Pediatric airway obstruction due to ectopic thyroid Laryngoscope 1998;98:422-6. line pharyngotomy that is either transhyoid, suprahyoid or infrahyoid or through a lateral pharyngotomy.

Some authors ${ }^{16}$ combine transoral and transcervical techniques in the management of lingual thyroid, obtaining the benefits of each method. Moving the posterior portion of the gland by means of a pharyngotomy allows the control of areas with a high risk of hemorrhaging. This permits the mass to then be displaced anteriorly so that complete resection is facilitated. A new approach is presented in this clinical case that combines an initial extraoral technique using a midline cervicotomy followed by a pull-through and a final midline glossotomy. In this way clear exposure of the lesion is assured which allows for total excision with adequate control of vital cervical structures while not morbility is not added to the classical procedures.

Autotransplantation of lingual thyroid following excision is indicated in patients lacking normally functioning thyroid tissue which is not situated in the midline of the tongue. The tissue is implanted as a free graft under the fascia of the anterior rectus abdominis muscle or into the submandibular region following sectioning into layers with a 4-5 mm thickness. ${ }^{17}$ Treatment with thyroxin is not administered during the immediate postoperative [period] in order to prevent the graft from being suppressed. Some $30 \%$ of the patients remain euthyroid with no thyroxin therapy. ${ }^{6}$

An alternative to autotransplantation consists in the transposition of the lingual thyroid from the base of the tongue to the submandibular region through a lateral suprahyoid pharyngotomy. ${ }^{18} \mathrm{~A}$ pedicled flap is made, with random lingual muscle, which acts as a vehicle for the lingual thyroid. According to the authors, this offers a better result regarding thyroid function when compared with excision and autotransplantation. They defend that its new location is more accessible with regard to possible exploration in the event of hypertrophy or malignancy.

The use of laser has been described in the surgical management of lingual thyroid in a six-year-old boy. ${ }^{19}$

\section{Conclusions}

Even though the transoral techniques are simple and satisfactory for managing small lesions, the cervical approach is essential for the management of large lingual thyroids which are deep into the muscle. The combination of techniques increases tumor exposure, ensuring complete resection and minimizing intraoperative morbility derived from the control of vital cervical structures. 